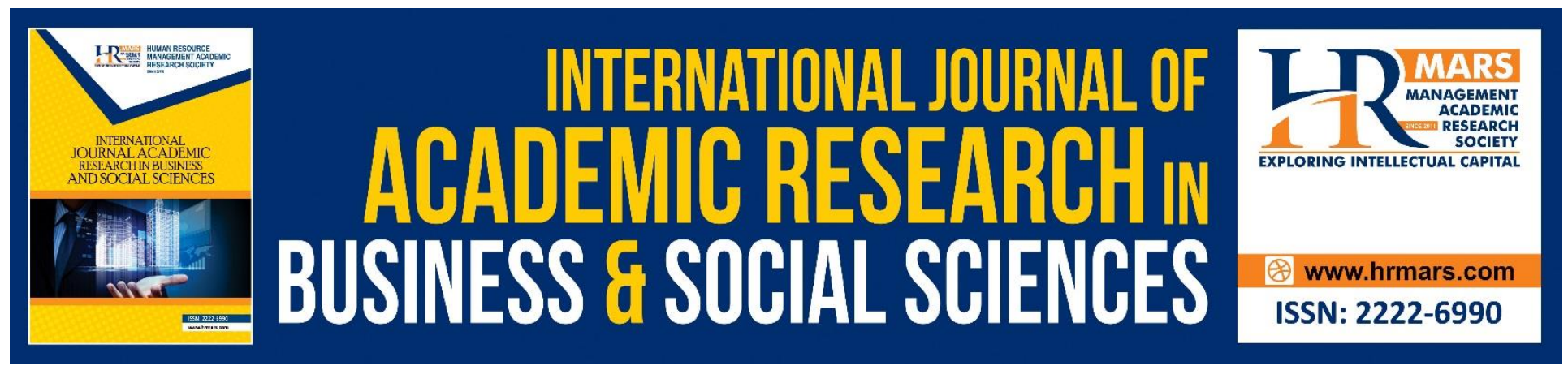

\title{
Effects of Poverty on Educational Attainment of Secondary School Students in Emohua Local Government Area of Rivers State, Nigeria
}

Okanezi, Bright \& Adeagbo, Bridget Peace

To Link this Article: http://dx.doi.org/10.6007/IJARBSS/v8-i7/4415

DOI: $\quad 10.6007 /$ IJARBSS/v8-i7/4415

Received: 21 June 2018, Revised: 03 July 2018, Accepted: 22 July 2018

Published Online: 28 July 2018

In-Text Citation: (Okanezi \& Adeagbo, 2018)

To Cite this Article: Okanezi, B., \& Adeagbo, B. P. (2018). Effects of Poverty on Educational Attainment of Secondary School Students in Emohua Local Government Area of Rivers State, Nigeria. International Journal of Academic Research in Business and Social Sciences, 8(7), 727-736.

\section{Copyright: (C) 2018 The Author(s)}

Published by Human Resource Management Academic Research Society (www.hrmars.com)

This article is published under the Creative Commons Attribution (CC BY 4.0) license. Anyone may reproduce, distribute, translate and create derivative works of this article (for both commercial and non-commercial purposes), subject to full attribution to the original publication and authors. The full terms of this license may be seen at: $\underline{\text { http://creativecommons.org/licences/by/4.0/legalcode }}$

Vol. 8, No. 7, July 2018, Pg. 727 - 736

Full Terms \& Conditions of access and use can be found at http://hrmars.com/index.php/pages/detail/publication-ethics 


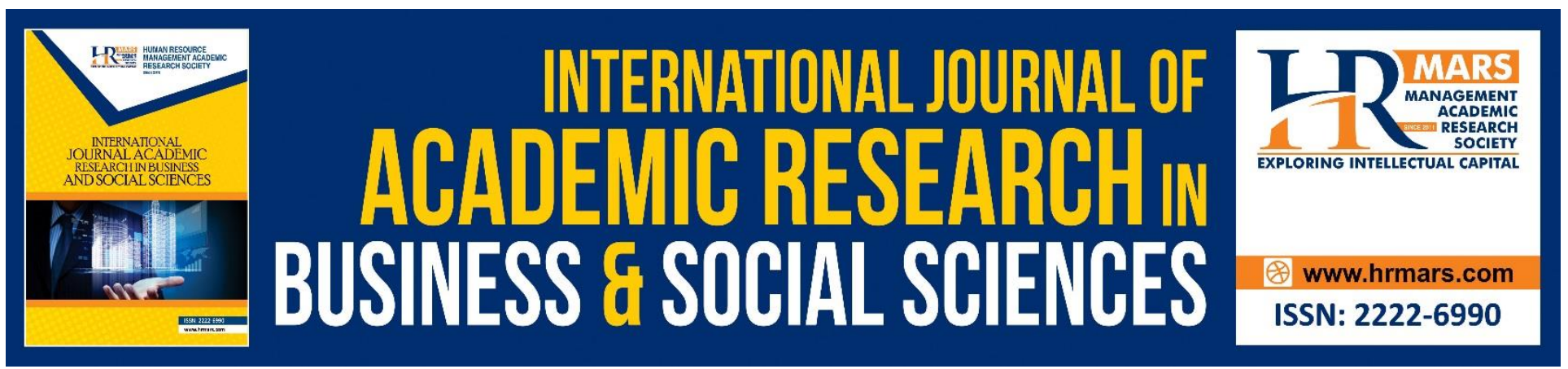

\title{
Effects of Poverty on Educational Attainment of Secondary School Students in Emohua Local Government Area of Rivers State, Nigeria
}

\author{
Okanezi, Bright (Ph.D) \\ Department of Educational Foundations, Faculty of Education, University of Port Harcourt \\ Email: bokanezi@yahoo.com \\ Adeagbo, Bridget Peace \\ Department of Educational Foundations, Faculty of Education, University of Port Harcourt
}

\begin{abstract}
This study investigated the effects of poverty on educational attainment of secondary school students in Emohua Local Government Area (LGA) of Rivers State, Nigeria. The study design was descriptive survey. The population of the study is 8,560 members of Youth Clubs/Associations in the LGA. The sample size used for the study was 865 youths which represents $10 \%$ of the study population. Data were collected through questionnaire on whether poverty of parents affect their ward's performance in examinations, the quality of schools they attend, and the level of education ultimately attained. Analysis was done using mean statistical tool for the research questions while chi-square was used to test the hypotheses at 0.05 alpha levels. The findings reveal that poverty of parents negatively affect their ward's academic performance, the quality of schools their wards attend and the level of education ultimately attained. Recommendations were made inter alia that government should establish a social welfare scheme for the poor and needy.
\end{abstract}

\section{Introduction}

The existence of creatures in pairs exemplifies the beauty of nature in creation. For instance there is the existence of real world and abstract world, the up and down, male and female, the tall and short, the beautiful and urgly, the young and old, the good and bad, richness and poverty etc. Giving explanation to the concept of poverty therefore, one would say that it is a condition whereby the person or nation being described is poor. Hornby (2000:910) defines poverty as "the state of being poor, a lack of something; poor quality. Also the World Bank (1995:52) defined poverty as "the inability to attain a minimal standard of living". Three poor families in three countries viz Ghana, Peru and Bangladesh were compared in a poverty study by the World Bank and their findings led to the conclusion that they lived under socio-economic conditions viewed as similar. Those conditions include lack of education, landlessness, acute vulnerability to illness and seasonal hard times which 
INTERNATIONAL JOURNAL OF ACADEMIC RESEARCH IN BUSINESS AND SOCIAL SCIENCES Vol. 8, No. 7, July 2018, E-ISSN: 2222-6990 @ 2018 HRMARS

affected all of them in varying degrees. The varying degrees is akin to researchers' problem of trying to establish a fixed standard against which to measure poverty. Against this back drop, it has been established that there is relative poverty and absolute poverty.

Absolute Poverty is viewed by Macionis (1994:173) as "deprivation of resources that is lifethreatening. It is the more serious, if solvable, human problem". Absolute poverty is often known as subsistence poverty since it is based on assessments of minimum subsistence requirements. In line with the above view,

the United Nations (1995) defined absolute poverty as "a condition characterized by severe deprivation of basic human needs, including food, safe drinking water, sanitation facilities, health, shelter, education and information. It depends not only on income but also on access to services". Also Abercrombie, Hill and Turner (2000: 278-274) posit that absolute poverty occurs "when people fail to receive sufficient resources to support a minimum of physical health and efficiency, often expressed in terms of calories or nutritional levels".

On the other hand, relative poverty is seen as universal and it refers to deprivation in relation to the greater resources of others. The proponents of relative poverty are of the view that a definition must relate to the standards of a particular society at a given time. In other words, the rate of affluence of a society will determine the yardstick for categorizing some people as poor hence different from other members of the society (Haralambos, Holborn, Chapman and Moore 2013: Macionis, 1994). It is therefore understandable that definitions of poverty cannot be static if it is based on relative standards especially in a dynamic world. In such consideration, what used to be luxury at a time past, may become a necessity in the present time. In the same vein, Abercrombie et al (2000) posit that:

relative poverty is defined by the general standards of living in different societies and what is culturally defined as being poor rather than some absolute level of deprivation. When poverty is defined relatively, by reference to the living standards enjoyed by the bulk of the population, poverty levels vary between societies and within societies over time pp 274.

At this juncture it is pertinent to state that whether relative or absolute, poverty is state of being poor. And for the purpose of this paper, we shall rely more on the absolute poverty hence poverty line or level would be explicated. According to Hornby (2000:910) poverty line also known as poverty level is "the official level of income that is necessary to be able to buy the basic things you need such as food and clothes and to pay for somewhere to live".

In Nigeria, majority of the citizens are living in poverty with regards to the state of the economy and the living standard of the populace. A pointer to the above assertion is the Nigeria's misery index which is exemplified in the increased unemployment, poverty rate, loss of global competitiveness and extremely high exchange rate of over N300/\$1 (three hundred naira per dollar). The misery index as at December, 2016 stood at 49.5\%, Nigeria is said to be the fourth most miserable country in the world (Okereocha, 2016).

Having established the fact that poverty is ravaging Nigeria, it becomes imperative that the causes of poverty be unraveled. Njoku (2004:124-137) outlined the causes of the increasing poverty in Nigeria as follows:

1. Increasing problem of scarce resources 
INTERNATIONAL JOURNAL OF ACADEMIC RESEARCH IN BUSINESS AND SOCIAL SCIENCES

Vol. 8, No. 7, July 2018, E-ISSN: 2222-6990 @ 2018 HRMARS

2. Impact of environmental degradation

3. The problem of unemployment

4. Decline in agricultural production

5. Illiteracy

6. Poor implementation of programmes

$7 . \quad$ Decline in the value of Naira

8. Lack of access to capital for investment

9. Lack of basic skills

10. The widening gap in the incomes of the rich and poor citizens

11. Impact of globalization

12. Low prices of cash crops in international markets.

Having outlined the causes of poverty in Nigeria, it is pertinent at this juncture to discuss the concept of academic attainment. Attainment is synonymous with achievement. Achievement refers to a thing that somebody has done successfully as a result of his own effort and skill. From the above explication, it becomes clear that attainment is the success in achieving something. Academic achievement is the extent to which an individual performs in a given academic task. The performance most often is related to the height one reaches in the line of academics. In support of the explanation of academic achievement, Okeke (2002:69) considered it to be "an individual's performance in class tests as well as the level of education ultimately attained". This definition makes it more understandable that it refers to whatever the individual performance in class tests or examinations and also the highest level of education the individual has acquired. Since society is made up of the rich and the poor and both are free to aspire to any level of education, the researchers therefore deem it necessary to investigate if poverty inhibits an individual's educational attainment.

\section{Statement of the Problem}

Ordinarily, society is free and open to its members. In order to actualize this ideology, Nigeria enshrined it in her five main national goals -a just and egalitarian society (Federal Republic of Nigeria 2004:6). To ensure the achievement of this all important national goal, Universal Basic Education was launched. According to the Federal Republic of Nigeria, FRN (2004:13) "Basic education shall be of 9year duration comprising 6 years of primary education and 3 years of junior secondary education. It shall be free and compulsory".

Besides, the school is open to all and the same curriculum is made for all the schools yet some perform excellently while others perform below average. Moreso, it is alleged that some individuals or students end up their career at the 3 years of junior secondary school. Even, those that continue in the senior secondary school find it difficult to finish. Most of them do not register for Senior School Certificate Examination, SSCE conducted by both the West African Examination Council (WAEC) and the National Examinations Council (NECO). It is equally on record that performance in these examinations has been poor for over a decade. Furthermore, very few attempt the Unified/Tertiary Matriculation Examination UTME conducted by the Joint Admissions and Matriculation Board (JAMB). It is also alleged that performances in the UTME has been poor. What then is the cause of all these? Could it be effect of poverty? The researchers are concerned with these negative development hence the decision to embark on this study. 
INTERNATIONAL JOURNAL OF ACADEMIC RESEARCH IN BUSINESS AND SOCIAL SCIENCES Vol. 8, No. 7, July 2018, E-ISSN: 2222-6990 @ 2018 HRMARS

\section{Aim and Objectives}

The aim of the study is to unravel the effects of poverty on the educational attainment of secondary school students in Emohua Local Government Area of Rivers State. Specifically the study is to:

1. find out whether parents' income affects students performance in class tests and examinations

2. ascertain whether the quality of school a child attends is dependent on the parents' income

3. determine whether the level of education ultimately attained by the child is influenced by his parents' income.

\section{Research Questions}

The following research questions were formulated to the guide the study in achieving its objectives thus:

1. Does parents' income affect student's performance in class tests and examinations?

2. Does parents' income influence the quality of school their ward attend?

3. Does parents' income influence the level of education ultimately attained by the child?

\section{Hypotheses}

$\mathbf{H o}_{1}$ There is no significant relationship between parents' income and the students' performance in class tests/examinations

$\mathrm{Ho}_{2}$ There is no significant relationship between parents' income and the quality of school their ward attends.

$\mathrm{Ho}_{3}$ There is no significant relationship between parents' income and the level of education the child ultimately attains.

\section{Methodology}

Descriptive survey design was employed to unravel the effects of poverty on the educational attainment of some youths in Emohua Local Government Area of Rivers State, Nigeria. The population for the study is 8, 560 members of youth clubs/associations in the Local Government Area. The sample size used for the study is 865 which represents $10 \%$ of the study population. The study employed stratified random sampling technique as well as simple random sampling technique. The instrument for data collection is a structured questionnaire designed by the researchers. It was a 12 item instrument designed in a four point Likert scale responses of Strongly Agree (SA), Agree (A), Disagree (D), and Strongly Disagree (SD). The instrument is made up of two sections. Section ' $A$ ' elicited the respondents' bio-data while section ' $B$ ' elicited information on the research questions. The researchers personally administered the instrument and also retrieved them accordingly. The data collected were analysed using Mean statistical tool for the research questions and chi-square statistic for the hypotheses.

\section{Results}

Research Question 1: Does Poverty of parents affect students' performance in class tests/examinations in Emohua L.G.A of Rivers State, Nigeria. 
INTERNATIONAL JOURNAL OF ACADEMIC RESEARCH IN BUSINESS AND SOCIAL SCIENCES

Vol. 8, No. 7, July 2018, E-ISSN: 2222-6990 (C) 2018 HRMARS

Table 1: Responses and mean score analysis of whether poverty of parents affect students' performances in class tests/examinations.

\begin{tabular}{|l|l|l|l|l|l|l|l|l|}
\hline S/N & \multicolumn{1}{|c|}{ ITEMS } & \multicolumn{1}{|c|}{ SA } & D & SD & TOTAL & $\bar{X}$ & $\begin{array}{l}\text { DECl- } \\
\text { SION }\end{array}$ \\
\hline & $\begin{array}{l}\text { Do you agree that the following } \\
\text { are effects of poverty on } \\
\text { students' } \\
\text { tests/examinations class }\end{array}$ & & & & & & \\
\hline 1 & You do not have books to read & $\begin{array}{l}298 \\
(1192)\end{array}$ & $\begin{array}{l}342 \\
(1026)\end{array}$ & $\begin{array}{l}150 \\
(300)\end{array}$ & $\begin{array}{l}75 \\
(75)\end{array}$ & $\begin{array}{l}865 \\
(2593)\end{array}$ & 3.0 & Agree \\
\hline 2 & $\begin{array}{l}\text { You are over burdened with } \\
\text { domestic chores }\end{array}$ & $\begin{array}{l}254 \\
(1016)\end{array}$ & $\begin{array}{l}376 \\
(1128)\end{array}$ & $\begin{array}{l}112 \\
(224)\end{array}$ & $\begin{array}{l}123 \\
(123)\end{array}$ & $\begin{array}{l}865 \\
(2491)\end{array}$ & 2.9 & Agree \\
\hline 3 & $\begin{array}{l}\text { The home environment you live } \\
\text { is unconducive for learning }\end{array}$ & $\begin{array}{l}301 \\
(1204)\end{array}$ & $\begin{array}{l}283 \\
(849)\end{array}$ & $\begin{array}{l}156 \\
(312)\end{array}$ & $\begin{array}{l}125 \\
(125)\end{array}$ & $\begin{array}{l}865 \\
(2490)\end{array}$ & 2.9 & Agree \\
\hline 4 & $\begin{array}{l}\text { Your parents could not afford to } \\
\text { pay for extra-mural classes }\end{array}$ & $\begin{array}{l}266 \\
(1064)\end{array}$ & $\begin{array}{l}356 \\
(1068)\end{array}$ & $\begin{array}{l}92 \\
(184)\end{array}$ & $\begin{array}{l}151 \\
(151)\end{array}$ & $\begin{array}{l}865 \\
(2467)\end{array}$ & 2.9 & Agree \\
\hline & Grand mean & & & & & & & \\
\hline
\end{tabular}

Table 1 above has a grand mean of 2.9 which implies that poverty affects performance in both class tests and examinations.

Research Question 2: Does parents' income influence the quality of schools their ward attend?

Table 2: Responses and mean score analysis of whether parents income influence the quality of school their wards attend.

\begin{tabular}{|l|l|l|l|l|l|l|l|l|}
\hline S/N & \multicolumn{1}{|c|}{ ITEMS } & \multicolumn{1}{|c|}{ SA } & \multicolumn{1}{|c|}{ D } & SD & TOTAL & $\bar{X}$ & $\begin{array}{l}\text { DECI- } \\
\text { SION }\end{array}$ \\
\hline & $\begin{array}{l}\text { Do you agree that parents' } \\
\text { income influence the quality of } \\
\text { schools their wards attend in } \\
\text { the following ways. }\end{array}$ & & & & & & \\
\hline 1 & My school lack laboratories & $\begin{array}{l}284 \\
(1136)\end{array}$ & $\begin{array}{l}426 \\
(1278)\end{array}$ & $\begin{array}{l}93 \\
(186)\end{array}$ & $\begin{array}{l}62 \\
(62)\end{array}$ & $\begin{array}{l}865 \\
(2662)\end{array}$ & 3.1 & Agree \\
\hline 2 & $\begin{array}{l}\text { We lack both library and ICT } \\
\text { facilities }\end{array}$ & $\begin{array}{l}331 \\
(1324)\end{array}$ & $\begin{array}{l}387 \\
(1161)\end{array}$ & $\begin{array}{l}80 \\
(160)\end{array}$ & $\begin{array}{l}67 \\
(67)\end{array}$ & $\begin{array}{l}865 \\
(2712)\end{array}$ & 3.1 & Agree \\
\hline 3 & $\begin{array}{l}\text { Most of the teachers are non- } \\
\text { professionals }\end{array}$ & $\begin{array}{l}260 \\
(1040)\end{array}$ & $\begin{array}{l}356 \\
(1068)\end{array}$ & $\begin{array}{l}101 \\
(202)\end{array}$ & $\begin{array}{l}148 \\
(148)\end{array}$ & $\begin{array}{l}865 \\
(2458)\end{array}$ & 2.8 & Agree \\
\hline 4 & $\begin{array}{l}\text { Each class is usually over } \\
\text { crowded }\end{array}$ & $\begin{array}{l}226 \\
(904)\end{array}$ & $\begin{array}{l}334 \\
(1002)\end{array}$ & $\begin{array}{l}155 \\
(310)\end{array}$ & $\begin{array}{l}150 \\
(150)\end{array}$ & $\begin{array}{l}865 \\
(2366)\end{array}$ & 2.7 & Agree \\
\hline & Grand mean & & & & & & 2.9 & \\
\hline
\end{tabular}

Table 2 above has a grand mean of 2.9 which indicates that parents' income influence the quality of schools their wards attend.

Research Question 3: Does parents' poverty affect the level of education ultimately attained by their wards? 
INTERNATIONAL JOURNAL OF ACADEMIC RESEARCH IN BUSINESS AND SOCIAL SCIENCES Vol. 8, No. 7, July 2018, E-ISSN: 2222-6990 @ 2018 HRMARS

Table 3: Responses and mean score analysis of whether parents' poverty affect the level of education ultimately attained by their wards.

\begin{tabular}{|c|c|c|c|c|c|c|c|c|}
\hline $\mathbf{S} / \mathbf{N}$ & ITEMS & SA & A & D & SD & TOTAL & $\bar{X}$ & $\begin{array}{l}\text { DECI- } \\
\text { SION }\end{array}$ \\
\hline & $\begin{array}{l}\text { Do you agree that parents' } \\
\text { poverty affect the level of } \\
\text { education ultimately attained } \\
\text { by their wards in the } \\
\text { following ways. }\end{array}$ & & & & & & & \\
\hline 1 & $\begin{array}{l}\text { Some students do not have } \\
\text { JSS3 certificate because of } \\
\text { lack of money for registration }\end{array}$ & $\begin{array}{l}214 \\
(856)\end{array}$ & $\begin{array}{l}396 \\
(1188)\end{array}$ & $\begin{array}{l}111 \\
(222)\end{array}$ & $\begin{array}{l}144 \\
(144)\end{array}$ & $\begin{array}{l}865 \\
(2410)\end{array}$ & 2.8 & Agree \\
\hline 2 & $\begin{array}{l}\text { Due to parents' poverty some } \\
\text { students could not register } \\
\text { for senior school certificate } \\
\text { exams. }\end{array}$ & $\begin{array}{l}237 \\
(948)\end{array}$ & $\begin{array}{l}383 \\
(1149)\end{array}$ & $\begin{array}{l}147 \\
(294)\end{array}$ & $\begin{array}{l}98 \\
(98)\end{array}$ & $\begin{array}{l}865 \\
(2489)\end{array}$ & 2.9 & Agree \\
\hline 3 & $\begin{array}{l}\text { Most SS3 students may not } \\
\text { obtain UTME forms because } \\
\text { their parents cannot afford it. }\end{array}$ & $\begin{array}{l}250 \\
(1000)\end{array}$ & $\begin{array}{l}275 \\
(825)\end{array}$ & $\begin{array}{l}143 \\
(286)\end{array}$ & $\begin{array}{l}197 \\
(197)\end{array}$ & $\begin{array}{l}865 \\
(2308)\end{array}$ & 2.7 & Agree \\
\hline 4 & $\begin{array}{l}\text { Many students drop out of } \\
\text { school due to inability to pay } \\
\text { school fees }\end{array}$ & $\begin{array}{l}226 \\
(904)\end{array}$ & $\begin{array}{l}298 \\
(894)\end{array}$ & $\begin{array}{l}141 \\
(282)\end{array}$ & $\begin{array}{l}200 \\
(200)\end{array}$ & $\begin{array}{l}865 \\
(2280)\end{array}$ & 2.6 & Agree \\
\hline & Grand mean & & & & & & 2.8 & \\
\hline
\end{tabular}

Table 3 above shows a grand mean of 2.8 which means that parents' poverty influences the level of education the child ultimately attained.

\section{Hypotheses}

$\mathrm{Ho}_{1}$ : There is no significant relationship between poverty of parents and students' performance in class tests/examinations.

Table 4: Chi-square statistic test of relationship between poverty of parents and students' performance in class tests/examinations.

\begin{tabular}{|l|l|l|l|l|l|l|l|}
\hline Variables & N & df & Sign/L & $\mathbf{X}^{2}$-cal & $\mathbf{X}^{2}$-tab & Decision \\
\hline $\begin{array}{l}\text { Poverty of } \\
\text { parents }\end{array}$ & $\begin{array}{l}\text { Academic } \\
\text { performance }\end{array}$ & 865 & 9 & 0.05 & 132.04 & 16.92 & Rejected \\
\hline
\end{tabular}

At 0.05 level of significance and 9 degree of freedom, $x^{2}$-cal is 132.04 and $x^{2}$-table is 16.92 . Since $x^{2}$ calculated is greater than $x^{2}$-table, the null hypothesis is therefore rejected, and the alternate hypothesis is accepted. This implies that academic performances of secondary school students in Emohua Local Government Area of Rivers State are affected by parents' poverty.

$\mathrm{Ho}_{2}$ : There is no significant relationship between poverty of parents and the quality of school their children attend. 
INTERNATIONAL JOURNAL OF ACADEMIC RESEARCH IN BUSINESS AND SOCIAL SCIENCES Vol. 8, No. 7, July 2018, E-ISSN: 2222-6990 @ 2018 HRMARS

Table 5: Chi-square statistic test of relationship between poverty of parents and the quality of schools their children attend.

\begin{tabular}{|l|l|l|l|l|l|l|l|}
\hline Variables & N & df & Sign/L & X $^{2}$-cal & X $^{2}$-tab & Decision \\
\hline $\begin{array}{l}\text { Poverty of } \\
\text { parents }\end{array}$ & $\begin{array}{l}\text { Quality of } \\
\text { school }\end{array}$ & 865 & 9 & 0.05 & 221.88 & 16.92 & Rejected \\
\hline
\end{tabular}

At 0.05 level of significance and degree of freedom of 9, the $x^{2}$ - calculated is 221.88 and $x^{2}$ table value is 16.92. Since $x^{2}$ - cal is greater than $x^{2}$ table value, the null hypothesis is therefore rejected and the alternate hypothesis is accepted. This implies that there is a significant relationship between poverty of parents and the quality of schools their ward attends. In other words, poverty of parents affects the quality of schools their wards attend.

Ho3: There is no significant relationship between poverty of parents and the level of education ultimately attained by their children.

Table 6: Chi-square statistic Test of relationship between poverty of parents and the level of education their children ultimately attain.

\begin{tabular}{|l|l|l|l|l|l|l|l|}
\hline Variables & N & df & Sign/L & $\mathbf{X}^{2}$-cal & $\mathbf{X}^{2}$-tab & Decision \\
\hline $\begin{array}{l}\text { Poverty of } \\
\text { parents }\end{array}$ & $\begin{array}{l}\text { Education } \\
\text { ultimately } \\
\text { attained by } \\
\text { children }\end{array}$ & 865 & 9 & 0.05 & 164.84 & 16.92 & Rejected \\
\hline
\end{tabular}

At 0.05 level of significance and degree of freedom of 9 , the $x^{2}$ calculated is 164.85 and $x^{2}$ table value is 16.92. Since $x^{2}$ calculated value is greater than $x^{2}$ Table value, the null hypothesis is therefore rejected and the alternate hypothesis is accepted. This implies that there is significant relationship between poverty of parents and the level of education their children ultimately attain. This means that poverty of parents affect the level of education their children ultimately attain.

\section{Discussion}

The first finding of the study is that poverty of parents affects students' academic performances in both class tests and external examinations. The study revealed that poverty manifests in lack of books to read, students over burdened with domestic chores, home environment unconducive for learning and inability to afford to pay for extra-mural classes. Inability of parents to buy books for their wards to read results in serious set back for the students' academic performance. The above assertion is supported by Okeke (2002:71) who pointed out that "the differences in socio-economic status of parents also create differences at the rate parents meet with both material and financial requirements for their children's academic success in school". Also, the children from poor homes are often over burdened with domestic chores. Some are asked to hawk acamo, acra, kerosene, etc. in the morning before going to school. This is mainly to support the family economy. This could result in lateness to school and also affect the rate of class attendance. Besides, most home environment of the poor is not conducive for learning. Such homes usually lack good reading table and chair, the children sit on the ground to read and write. They also lack computers and other basic requirements necessary for studying. Moreso, the home environment where the poor live may not be an 
INTERNATIONAL JOURNAL OF ACADEMIC RESEARCH IN BUSINESS AND SOCIAL SCIENCES

Vol. 8, No. 7, July 2018, E-ISSN: 2222-6990 @ 2018 HRMARS

enlightened environment and as such may not be encouraging academic hard work. It is equally glaring that the poor hardly have spare money to engage a private teacher to teach his child after school or to enroll for extra-mural classes. All these negatively affect the child's academic performance.

The study also reveals that parents' income influence the quality of schools their ward attend. The finding of the study is that most of the schools attended by the children of the poor lack laboratories, libraries, Information and Communication Technology (ICT) facilities etc. Some of the teachers are non-professionals, and the classrooms are usually overcrowded. It is understandable that most of the poor dwell in rural areas with their children. The findings of this study is therefore given credence by Okeke (2002) who posits thus:

Poor academic performance of children in the rural areas could also be attributed to insufficient qualified teachers in these areas. Lack of basic infrastructure in schools such as study-tables, libraries, laboratories of different types, residential accommodation for workers and other essential social amenities including pipe-borne water, water-system toilet, electricity and good roads will discourage many qualified staff to settle there comfortably pp 78.

Also the UNESCO recommendation or standard of 30 students per teacher is not practiced in most of the schools and more of the students in such schools are children from low socio-economic background.

Furthermore, the finding of the study is that parents' poverty influence the level of education ultimately attained by their wards. Some students from poor background could not obtain Junior Secondary School Certificate because there was no money to register for the examination. Some students suffer the same fate in the Senior Schools Certificate Examination registration. It therefore follows that some students from poor background end up their education career in JSS 3, some at SS3, some cannot obtain form for Unified Tertiary Matriculation Examination (UTME) while some drop out of school at either JSS1, JSS2, SS1 or SS2. The above findings is supported by Musbau (2017:18) as he posits that "indeed poverty not only lies at the heart of the factors that hinder access to education but continues to be the main obstacle to achieving the goal of universal education in the country".

\section{Conclusion}

Poverty affects people both psychologically and socially. It translates in the fact that more of the children from low socio-economic background perform comparatively low in academics, attend low quality schools and often dropout of school without attaining appreciable level of education.

\section{Recommendations}

Based on the findings of the study, the following recommendations were made:

- $\quad$ Government should establish social welfare scheme for the poor or needy.

- $\quad$ The various tiers of government should prioritize education in their annual budget and ensure quality education is provided for all her citizens

- $\quad$ Since unemployment is closely linked to poverty, government at all levels should create employment opportunities to reduce the rate of poverty.

- $\quad$ A good policy should be made to reverse the trend of the growing population of out of school children. 
INTERNATIONAL JOURNAL OF ACADEMIC RESEARCH IN BUSINESS AND SOCIAL SCIENCES

Vol. 8, No. 7, July 2018, E-ISSN: 2222-6990 (C) 2018 HRMARS

- $\quad$ Parents should be orientated to know that they are duty bound to sponsor their children's education hence they should bear only the number of children they can train

- $\quad$ Students should be counseled to know that inspite of parents' poverty, they can still excel if they work hard.

\section{References}

Abercrombie, N., Hill, S., \& Turner, B.S. (2000), The Penguin dictionary of sociology $\left(4^{\text {th }}\right.$ ed). London: Penguin Books.

Federal Republic of Nigeria (2004). National Policy on education $\left(4^{\text {th }}\right.$ ed). Yaba, Lagos: NERDC Press.

Haralambos, M., Holborn, M., Chapman, S., \& Moore, S. (2013). Sociology: Themes and Perspectives $\left(8^{\text {th }} \mathrm{Ed}\right)$. Hammersmith London: Harpercollins publishers.

Hornby, A.S. (2000). Oxford Advanced Learner's dictionary ( $6^{\text {th }}$ ed). Oxford: Oxford University Press.

Macionis, J.J. (1994). Society: The basics. Englewood Cliffs, New Jersey: Prentice Hall.

Musbau, R. (2017, August 15). Population, education and Nigeria's cycle of poverty. The Guardian 34 $(14,109), 18$.

Njoku, A.O. (2005). Contemporary public issues in social studies education in Nigeria. (2 ${ }^{\text {nd }}$ ed), Enugu: Redeemed Printing and publishing.

Okeke, E.C. (2002). Education and social stratification. In E.C. Okeke (ed). Sociology of Education: concepts and Applications. Owerri: Springfield-publishers.

Okereocha, C. (2016, December 9). Recession pushes up Nigeria's misery index. The Nation 2 (3791), 14.

United Nations (1995). The Copenhagen Declaration and Programme of Action: World Summit for Social Development. New York: United Nations.

World Bank (1995). "What do we know about the poor" In R. Aryes (ed.) Development studies: An introduction through selected readings. Dartford, U.K.: Greenwich University Press. 